\title{
СУТНІСТЬ І ОСОБЛИВОСТІ РОЗВИТКУ РОЗДРІБНИХ ТОРГОВЕЛЬНИХ МЕРЕЖ В УКРАЇНІ
}

\author{
Данило Світлана Іванівна \\ кандидат економічних наук \\ Ужгородський торговельно-економічний інститут КНТЕУ (м. Ужгород, Україна) \\ ORCID: 0000-0003-3300-7172 \\ kveta_utei@ukr.net
}

У статті розглянуто особливості формування і розвитку роздрібних торговельних мереж. Розглянуто класифрікації підприємств роздрібної торгівлі. Запропоновано характеристику та вимоги до форматів роздрібних мереж. Надано рекомендації щодо поліпшення діяльності роздрібних мереж. Встановлено, що незважаючи на нестабільну політичну та економічну ситуацію, високу тіньову складову бізнесу в країні, мережа роздрібної торгівлі залишається однією з небагатьох галузей, яка розвивається і не тільки збільшує власні прибутки, а й є помітною підтримкою всієї економіки країни.

Ключові слова: конкурентоспроможність, роздрібна торгівля, торговельні мережі, споживачі, фрормати магазину. DOI: https://doi.org/10.32845/bsnau.2019.3.27

Постановка проблеми. В сучасних умовах розвитку економіки важливого значення набувають роздрібні мережі, які забезпечують споживачам можливість швидко, зручно, з мінімальною витратою сил і часу придбати потрібні товари і послуги в умовах вільного вибору і широкого асортименту, недалеко від місця роботи або проживання, в потрібну годину та певної кількості. Через постійне вдосконалення форм та методів торгівлі, уніфікацію товару, конкуренцію, зміну ознак, фактори впливу на роздрібну торгівлю та її класифікацію, доцільно з часом уточнювати класифікаційні ознаки, характеристики і вимоги до сучасних форматів магазинів для більш прибуткової їх діяльності. Таким чином розвиток роздрібних мереж набуває все нового і необхідного значення.

Аналіз останніх досліджень та публікацій. Питанням функціонування та розвитку роздрібної торгівельної мережі приділено достатньо багато уваги у працях вітчизняних та зарубіжних дослідників, зокрема О. Азарян [1], В. Апопія [2], Т. Васильціва [3], Д. Гілберта, В. Лагутіна, Л. Ларіної, М. Леві, Л. Лігоненко [4], В. Лісіци [5], Н. Попадинця [6-8], Ю. Родінова, А. Садекова та ін. Однак варто зазначити, що саме особливостям розвитку роздрібних торговельних мереж на території України приділено не так і багато досліджень.

Метою статті $€$ дослідження сутності та визначення особливостей розвитку роздрібної торговельної мережі в Україні.

Виклад основного матеріалу. Сьогодні торгівля відображає основні перспективи і проблеми економіки країни. Сфера торгівлі забезпечує п'яту частину обсягу внутрішнього валового продукту, послугами торгівлі користується все населення країни, яка не тільки набуває необхідні товари, але і має можливість отримати додаткові вигоди і враження від відвідування торгових підприємств.

Значний вплив на роздрібну торгівлю надає стрімкий розвиток ряду процесів в економіці держави. Система цінностей і спосіб життя споживачів були диверсифіковані за дуже короткий період, акценти з функціональних властивостей матеріальних продуктів зміщені на якість представлених послуг. Інформатизація систем поводження привела до виникнення нових видів торгівлі, тобто інтернаціоналізації сфери обігу на основі глобалізованої економіки, різке розшарування суспільства за рівнем життєвого доходу.
Сьогодні на ринку збільшується число торгових підприємств, таких як супер і гіпермаркети. Рівень конкуренції в секторі роздрібної торгівлі радикально змінюється. Присутність великої кількості операторів в роздрібній торгівлі можна пояснити такими чинниками:

- низькі вхідні бар'єри дозволяють деяким фірмам легко увійти в бізнес, оскільки для відкриття справи не потрібно значних коштів, великого торгового приміщення і дорогого обладнання;

- попит на ринку різноманітний як за товарним асортиментом, так і за ціновим діапазоном, що дозволяє існувати великій кількості фірм, що спеціалізуються на різних сегментах ринку;

- обслуговуються групи населення обмежені географічно (пішохідна доступність, район міста, місто), тому місцеві підприємства, особливо дрібні, легше проникають на невеликі ділянки збуту і більш чутливо реагують на найменшу зміну попиту, краще знають смаки і потреби цільових покупців, що створює відповідні конкурентні переваги;

- відсутність суттєвої економії на масштабах діяльності одиночного підприємства в зв'язку з обмеженням економічно розумного радіусу залучення покупців дозволяє дрібним підприємствам конкурувати з великими підприємствами.

Завдяки збільшенню кількості роздрібних мереж, загальної стратегії маркетингу торговельного підприємства, правилам їх розташування, впливу економічної ситуації регіону та споживацької поведінки відбувається переорієнтація споживачів на формат невеликих магазинів, які охоплюють різні сегменти ринку.

Для того щоб якомога більшу кількість споживачів залучити у власну роздрібну мережу, все більше власників використовують магазини різних форматів. На нашу думку, при обиранні формату магазину повинно бути визначено: кількість та повноту асортиментних ліній; ціновий діапазон пропонованого асортименту; перелік сервісних послуг; план руху потоку споживачів у торговельному залі; торгівельне обладнання, його кількість, розміри в залежності від асортименту магазину; атмосфреру магазину (колір, освітлення, музикальний супровід, зручність під'їзів до магазину) (табл. 1).

\section{Класифікація форматів магазинів}




\begin{tabular}{|c|c|}
\hline Назва & Jinge oveniy \\
\hline Гіпермаркет & $\begin{array}{l}\text { газин самообслуговування з торговою площею більше } 5000 \text { м², із широким спектром продовольчих і непродовольчих } \\
\text { зарів }\end{array}$ \\
\hline Супермаркет & $\begin{array}{l}\text { Магазин самообслуговування з торговою площею від 2,5 до } 5 \text { тис. м². Широкий спектр продовольчих товарів, і в силу } \\
\text { площі менша кількість непродовольчих товарів }\end{array}$ \\
\hline $\begin{array}{l}\text { Економний } \\
\text { супермаркет }\end{array}$ & $\begin{array}{l}\text { Великий формат (від 2,5 тис. м²) універсальної торгівлі, орієнтованої на низькі ціни, з широким асортиментом } \\
\text { непродовольчих товарів, товарів по догляду за тілом, продовольчих товарів (30-40\% асортименту). Найбільш } \\
\text { популярні в Північній Америці }\end{array}$ \\
\hline Склад-клуб & $\begin{array}{l}\text { Торговий об'єкт великої площі, який реалізує товари як корпоративним (оптовий продаж В2В), так й індивідуальним } \\
\text { клієнтам (роздріб В2С), що є членами клубу. Останні зазвичай зобов'язані вносити щорічну плату. Формат особливо } \\
\text { широко поширений у Північній Америці }\end{array}$ \\
\hline ичний & $\begin{array}{l}\text { Магазин самообслуговування з торговою площею від } 400 \text { до 2,5 тис. м², що спеціалізується, як правило, на продажу } \\
\text { продовольчих товарів }\end{array}$ \\
\hline Магазин біля дому & 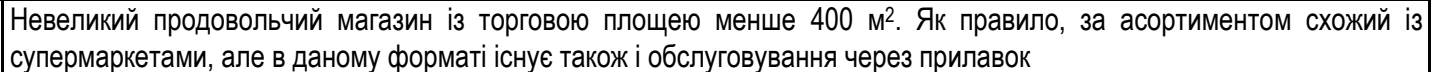 \\
\hline $\begin{array}{l}\text { Продовольчий } \\
\text { відділ }\end{array}$ & $\begin{array}{l}\text { Відділ із роздрібної торгівлі продовольчими товарами в більш великому торговому об'єкті, як правило, займає цілий } \\
\text { поверх }\end{array}$ \\
\hline Гастроном & $\begin{array}{l}\text { Невеликий за площею магазин, як правило, спеціалізується на специфічних видах продовольчих товарів (м'яса, вина, } \\
\text { сиру), а також ураховує національні та регіональні уподобання споживачів }\end{array}$ \\
\hline $\begin{array}{l}\text { Цілодобовий } \\
\text { магазин }\end{array}$ & $\begin{array}{l}\text { Невеликий продовольчий магазин, що відрізняється широким графіком роботи і помітним акцентом на таких факторах } \\
\text { зручності, як продаж готових страв і продуктів швидкого приготування. Крім того, представлені традиційні продовольчі } \\
\text { товари і незначний вибір непродовольчих }\end{array}$ \\
\hline Магазин при АЗС & $\begin{array}{l}\text { Як правило, розташовані при автозаправних станціях і орієнтуються на людей, які забули придбати що-небудь в } \\
\text { основних місцях покупки }\end{array}$ \\
\hline Діскаунтер е & $\begin{array}{l}\text { Продовольчий магазин із торговою площею від } 1000 \text { м². Формат найбільш поширений в Європі, де і з'явився } \\
\text { (Німеччина). Існує в двох різних версіях: жорсткий дискаунтер (harddiscountstore), який майже повністю орієнтований } \\
\text { на власні торгові марки і низький рівень цін; м'який дискаунтер (softdiscountstores), що пропонує більш широкий вибір } \\
\text { фрірмових виробів і свіжих продуктів харчування }\end{array}$ \\
\hline Аптека & іродажу лікарських препаратів, товарів по догляду за тілом \\
\hline $\begin{array}{l}\text { Магазин засобів } \\
\text { гігієни та косметики }\end{array}$ & $\begin{array}{l}\text { Магазини самообслуговування, то } \\
\text { товарами для здоров'я, аксесуарам }\end{array}$ \\
\hline $\begin{array}{l}\text { Магазин } \\
\text { алкогольної } \\
\text { продукції }\end{array}$ & Роздрібний магазин \\
\hline Виний бутік, паб & Магазин, що спеціалізується на продажі вина, пива (не обов'язково розтац \\
\hline Булочна & $\begin{array}{l}\text { ез прилавок) усі типи хлібобулочних виробів. } \\
\text { асре }\end{array}$ \\
\hline $\begin{array}{l}\text { Кондитерський } \\
\text { магазин }\end{array}$ & пропонує тістечка та інші специфічні борошняні вироби, а також ш \\
\hline $\begin{array}{l}\text { Магазин здорової } \\
\text { їжі }\end{array}$ & $\begin{array}{l}\text { Продовольчий магазин (іноді побудований на принципах самообслуговування), що пропонує здорові, природні і } \\
\text { органічні продовольчі продукти всіх типів. Розміри об'єкта можуть варіюватися в межах рівнів від магазину біля дому } \\
\text { до універсаму }\end{array}$ \\
\hline $\begin{array}{l}\text { Магазин } \\
\text { замороженої } \\
\text { продукції }\end{array}$ & $\begin{array}{l}\text { Продовольчий магазин, що спеціалізується на продажу одного або невеликої кількості певних типів продуктів } \\
\text { харчування. Існуючі формати спеціалізації включають: гастрономію, спиртні напої, вино, хлібобулочні вироби, сир, } \\
\text { м'ясні, рибні, дієтичні, органічні та заморожені продукти }\end{array}$ \\
\hline Кіоск & $\begin{array}{l}\text { і журнали, а також обмежений ассортимент продуктів харчування, солодощів, } \\
\text { через прилавок. Як правило, має тривалий графік роботи, що дозволяє йому } \\
\text { площа об'єкта знаходиться в діапазоні від } 10 \text { до } 50 \text { м² }\end{array}$ \\
\hline Торговий автомат & $\begin{array}{l}\text { Повністю автоматизований магазин, зазвичай розташований на залізничних станціях і в інших місцях із великими } \\
\text { людськими потоками. Як правило, здійснює продаж нешвидкопсувних продуктів, наприклад цукерок і безалкогольних } \\
\text { напоїв, але в ряді випадків також свіжих фруктів і бутербродів, молочної продукції } \\
\end{array}$ \\
\hline Автолавка & $\begin{array}{l}\text { Магазин на основі транспортного засобу, зазвичай продає основні продукти харчування всіх типів у віддалених } \\
\text { областях, де спостерігається дефіцит торговельних закладів. Існують також автолавки, що спеціалізуються на } \\
\text { заморожених продуктах харчування }\end{array}$ \\
\hline $\begin{array}{l}\text { Комбінований } \\
\text { продовольчий та } \\
\text { аптечний магазин } \\
\end{array}$ & $\begin{array}{l}\text { окий вибір продовольчих товарів та лікарських препаратів, які, як правило, не продаються } \\
\text { Іх магазинах }\end{array}$ \\
\hline $\begin{array}{l}\text { Будівельні } \\
\text { магазини }\end{array}$ & $\begin{array}{l}\text { Магазини різних форматів - від мінімаркетів до гіпермаркетів, що пропонують товари для будівництва, садівництва } \\
\text { та ремонту }\end{array}$ \\
\hline Універсам & \begin{tabular}{|l|} 
Розташований в центрі міста торговий об'єкт, що пропонує широкий вибір товарів (кожен в окремих департаментах), \\
включаючи одяг, господарські товари, меблі, канцелярське приладдя, а також продукти харчування
\end{tabular} \\
\hline Cash\&Carry & $\begin{array}{l}\text { Оптовий формат торгівлі, заснований на членстві і призначений для торгових посередників і комерційних клієнтів } \\
\text { (операторів магазинів і ресторанів) }\end{array}$ \\
\hline $\begin{array}{l}\text { Оптовий продс } \\
\text { доставкою }\end{array}$ & $\begin{array}{l}\text { Передбачає самообслуговування, оплату на касі (аналогічно супер- і гіпермаркетам) і самови-везе } \\
\text { товарів. У деяких країнах (наприклад, Східної Європи) торговельні об'єкти даного формату також реа }\end{array}$ \\
\hline
\end{tabular}




\begin{tabular}{|c|c|}
\hline Назва & Опис об'єкту \\
\hline & фізичним особам \\
\hline Продуктові послуги & $\begin{array}{l}\text { На відміну від Cash\&Carry, припускає доставку продовольчих і непродовольчих товарів покупцям за рахунок продавця. } \\
\text { Передбачає організовану поставку продуктів харчування і готових страв оптовим споживачам, включаючи готелі, } \\
\text { ресторани, їдальні, а також приватним та інституційним операторам кейтерінгу }\end{array}$ \\
\hline Товари для дітей & $\begin{array}{l}\text { Магазин, що спеціалізується виключно на товарах для дитячої аудиторії. Може мати дислокацію як усередині торгових } \\
\text { центрів, так і відокремлене місцерозташування. Відмінність від Department Store - у вузький спеціалізації }\end{array}$ \\
\hline $\begin{array}{l}\text { Побутова техніка } \\
\text { та електроніка }\end{array}$ & $\begin{array}{l}\text { Магазин, що спеціалізується виключно на продажах білої техніки (холодильники, пральні машини тощо) та електроніки. } \\
\text { Може мати форму або локалізованої торгової точки, або в якості якірних орендаторів }\end{array}$ \\
\hline Стоковий магазин & Магазини, де продаються фірмові залишки одягу чи взуття, які не були продані вчасно у фірмових магазинах \\
\hline Секонд-хенд & Магазин (secondhand-другі руки), де реалізуються дешеві непродовольчі товари, які були у вжитку \\
\hline Бутик & $\begin{array}{l}\text { Невеличкий спеціалізований магазин, який реалізує модні товари відомих марок (одяг, косметику) або товари } \\
\text { особливого попиту (вишукані марки вин) за високими цінами }\end{array}$ \\
\hline $\begin{array}{l}\text { «Спеціалісти } \\
\text { категорії» }\end{array}$ & $\begin{array}{l}\text { Магазини надвузького й одночасно надглибокого асортименту товарів, який обмежується товарними найменуваннями } \\
\text { однієї товарної групи }\end{array}$ \\
\hline Міні-маркет & 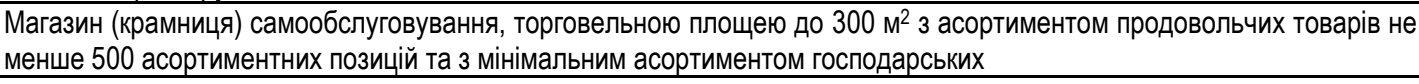 \\
\hline $\begin{array}{l}\text { Торговельний } \\
\text { центр }\end{array}$ & $\begin{array}{l}\text { Група роздрібних магазинів та закладів швидкого харчування, зосереджених в одному місці і керованих як одне ціле, } \\
\text { які за своїми типами, розмірами та місцем розташування функціонально відповідають потребам торговельної зони, } \\
\text { яку вони обслуговують }\end{array}$ \\
\hline Палатка, павільйон & $\begin{array}{l}\text { Торговельний об'єкт, призначений для продажу товарів кінцевим споживачам мінімального асортименту } \\
\text { господарських або продовольчих товарів, розміщений в окремій споруді полегшеної конструкції та має торговельну } \\
\text { залу для покупців }\end{array}$ \\
\hline
\end{tabular}

На основі інформації, наданої компанією GT Partners Ukraine, було проаналізовано найбільші мережі в столиці і регіонах України, що пропонують все, що потрібно для підтримання нормального життя: продукти, напої, предмети гігієни та товари для дому. Кожну мережу оцінювали за кількістю магазинів і сумарною площею. Основна мета дослідження з'ясувати, скільки всього торгових точок у лідерів ринку, в яких регіонах вони представлені, де вважають за краще відкривати магазини [11].

Так з 18 роздрібних операторів FMCG ринку в столиці найбільш потужно представлені вісім, зокрема найбільше торгових точок належить Fozzy Group (мережі Сільпо, Фора, Fozzy Cash \& Carry, Le Silpo, Thrash). Серед 199 магазинів $€$ супермаркет, магазин біля дому, cash \& carry, делікатес-маркет, дискаунтер. Відповідно, за розміром торгових площ цей оператор також на першому місці з показником 169500 кв. м. За обома показниками Fozzy Group з великим відривом випереджає дніпровську мережу АТБ з її 143 магазинами-дискаунтерами. Зрозуміло, для такого формату потрібні значно менші площі, а тому мережа АТБ за цим показником в Києві тільки на четвертому місці. Зате магазини Ашан конкурують 3 лідером не кількістю, а масштабом, посівши друге місце за площею - 98670 кв. м. Також варто звернути увагу на швидкий розвиток в столиці мереж невеликих форматів магазинів біля дому, таких як ЛотОК і Коло. За кількістю магазинів в Києві сумарно ці дві мережі вже можна порівняти з магазинами АТБ. А кожна з них окремо вже більше ніж мережа ЕКО маркет в столиці [11].

У північних регіонах країни, за винятком АТБ, в основному представлені мережі з київською пропискою, наприклад, Novus, яка має в своєму розпорядженні дев'ять магазинів формату супер- і гіперпермаркет. А також два гіпермаркети мережі Мегамаркет загальною площею 16740 кв. м. Примітно, що в регіоні розстановка сил за кількістю магазинів і обсягами торгових площ виглядає більш рівномірною. Можливо, тому що тут основна конкуренція між супер- і гіпермаркетами. Після Fozzy Group i АТБ трійку лідерів замикає ЕКО маркет, який крім перерахованих форматів також представлений магазинами біля дому.

У центральній частині України у п'ятірку регіональних мереж входить ще один місцевий гравець - ТОВ "НВП Аргон" з Вінниці, яке управляє мережами ГРОШ, ГРОШ експрес, КМаркет, Економ. Ці магазини працюють у форматах супермаркет, магазин біля дому, гіпермаркет, мінімаркет. Конкуруючи з дискаунтером АТБ, у якого тут в чотири рази більше торговельних точок і втричі - торговельних площ. Але разом два регіональних гравця цілком можуть змагатися за масштабами бізнесу 3 лідером. Крім магазинів Fozzy Group тут $€$ тільки ще одна національна мережа родом з Києва - Рітейл Груп - у якій тут вісім магазинів Велика Кишеня і Велмарт, представлених в форматах супер- і гіпермаркетів [11].

Аналогічна ситуація спостерігається і в південних регіонах, де 121 магазину найбільшої національної торгової мережі АТБ протистоять два місцевих рітейлера. Це торгова компанія АЛМІ, що управляє мережами магазинів Копійка, Копійка-мінімаркет і Santim, а також Таврія В, що розвиває однойменну мережу і делікатес-маркети Космос. 3 тією лише різницею, що сукупна "міць" цих мереж перевищує можливості лідера. Обидва місцевих гравця з Одеси і обидва представлені різними форматами: супермаркет, магазин біля дому, делікатес-маркет, мінімаркет. Причому Таврія В приблизно в два рази більше за площами, ніж всі її конкуренти [11]. У тому числі єдиного київського гравця - Fozzy, який саме в цьому регіоні відкрив магазини Le Silpo, щоб гідно конкурувати з місцевими делікатес-маркетами.

У західному регіоні переважають місцеві рітейлери 3 Луцька і Львова. Лідером за кількістю торговельних точок утримує Volwest Retail, розвиваюча мережі Наш Край і Spar в форматі супермаркету, магазину біля дому і мінімаркета. На другому місці компанія Львівхолод з її магазинами Рукавичка. У п'ятірку регіональних мереж входить також ПАККО Холдинг з Луцька, керуюча магазинами Вопак і Пакко, які працюють в форматі супермаркет, cash \& carry, магазин біля дому, мінімаркет. Але це, в основному, не дуже великі за площею тор- 
гові точки, тому мережі з півтора-двох сотень магазинів в сукупності не перевищують обсягів 38000 кв. м, у той час як Metro Cash \& Carry, у якої тут сім магазинів, має ту ж саму торговельну площу в 37300 кв. м. До речі, саме в цьому регіоні вельми популярний формат cash \& carry [11]. Його використовують три з п'яти найбільших мереж в регіоні. У тому числі компанія Fozzy, яка лідирує за кількістю квадратних метрів.

Однак саме на сході країни найбільш добре видно перевагу АТБ. Адже, цей регіон територіально ближче до головного офысу компанії, а також, це промислові регіони країни з найбільшою концентрацією потенційних покупців завжди були привабливі для розвитку рітейлу. Мережа - беззаперечний лідер як за кількістю магазинів так і за сумарною їх площею. Крім АТБ тут працює ще один локальний гравець 3 Дніпра - ТОВ "Омега", що розвиває мережі Varus, Varusmarket i Планета. Ці магазини працюють у форматі супермаркету, гіпермаркету, магазину біля дому, делікатес-маркет мінімаркет [11]. Це до речі, третій регіон, де різними мережами представлені делікатес-маркети. I саме ці два рітейлера конкурують в різних форматах з іншими гравцями. В іншому ж за масового споживача тут борються представники міжнародних рітейлерів: магазини Metro Cash \& Carry і гіпермаркети Ашан. Примітно, що у обох мереж однакова кількість магазинів і схожі площі.

Регіональний аналіз зацікавленості торговельних мереж у відкритті нових торговельних закладів показав, що спостерігається зміщення акцентів у західні регіони України. Упродовж 2018 р. і початку 2019 р. одна третина нових торговельних закладів була відкрита на заході країни.

Також варто зазначити, що зараз спостерігається активний розвиток роздрібного продуктової мережі. Присутність на ринку велику конкуренцію між компаніями, є потреба у розробленні та реалізації ефективних маркетингових стратегій, які дозволять максимізувати кількість клієнтів на довгостроковий період часу. Активний розвиток інноваційних технологій та їх упровадження у сфері цифрового маркетингу дає вітчизняній роздрібній мережі продуктового ринку широкі можливості для застосування передових підходів у процесі залучення цільової аудиторії. Як уже зазначалося заслуговує на увагу такий напрям торгівлі як замовлення товарів через Інтернет, у тому числі через мобільні додатки, оскільки поступово зростає чисельність клієнтів, які віддають перевагу придбанню товарів харчування завдяки технології е-commerce.
Варто зазначити, що динаміка показників електронної торгівлі України є набагато кращою за динаміку показників роздрібної торгівлі загалом. При цьому, хоча частка української електронної торгівлі становить біля 0,28\% обороту електронної торгівлі Європи загалом і 5,4\% цього обороту для Східної Європи [12], темпи зростання обороту електронної торгівлі України останніми роками суттєво перевищують темпи зростання у Європі. На думку експертыв це пов'язано у першу чергу з різким зростанням рівня проникнення Інтернет в Україні та розподілом Інтернет-користувачів України за віком та рівнем доходу: хоча загальний рівень проникнення Інтернету в Україні нині становить близько 64 \%, для користувачів з рівнем доходу вище середнього він сягає майже $100 \%$, аналогічна ситуація у віковій групі 15-45 років, яка забезпечує левову частку активних Інтернет-покупців [13].

Вікова структура українських Інтернет- користувачів дає змогу розглядати Інтернет як канал для формування споживчого попиту з найбільшою швидкістю та потенціалом зростання на найближчі роки. Основними чинниками цього $є, ~ з$ одного боку, поширення 3G інтернету та тотальна «мобілізація» споживачів, з другого, приналежність найбільшого сегменту Інтернет користувачів до поколінь X та Z, та економічна криза. Переваги Інтернет-торговців у порівнянні 3 традиційним рітейлом за рахунок нижчих цін, ширшого асортименту та швидшого знаходження потрібного товару лише посилюватимуться, причому найперспективнішою видається організація бізнесу за моделями електронного маркетплейсу та нішевого електронного магазину / електронної вітрини виробника [14].

Висновки. Як бачимо з дослідженого, що і сьогодні роздрібна торгівля залишається одним з тих видів економічної діяльності, який розвивається і не тільки збільшує власні прибутки, а й є помітною підтримкою всієї економіки країни. Вважаємо, що для посилення своїх позицій, утримання наявних та залучення нових клієнтів, збільшення власного прибутку та підвищення економіки держави кожне роздрібне підприємство має використовувати якомога більший комплекс заходів, а саме: систему мерчандайзингу - оптимізацію асортименту, ефективне планування торговельного залу, засоби комунікативного та візуального мерчандайзингу; покращання методів лояльності - для клієнтів, для посередників, для співробітників; удосконалення заходів матеріальної та моральної мотивації для співробітників; враховувати вимоги до форматів магазинів роздрібної мережі.

\section{Список використаної літератури:}

1. Азарян О. М., Локтєв Е. М., Саркісян Л. Г., Халлір Б., Соболєв В. О., Гаркуша Д. В. Сучасні тенденції розвитку роздрібної торговельної мережі. Донецьк: ДонДУЕТ. 2009. 226 с.

2. . Апопій В. В., Система регулювання внутрішньої торгівлі України. Київ: Академвидав. 2012. 420 c.

3. Васильців Т. Г., Волошин В. І., Бойкевич О. Р., Каркавчук В.В. Фінансово-економічна безпека підприємств України: стратегія та механізми забезпечення. Львів: «Ліга Прес». 2012. 386 с.

4. Лігоненко Л. О. Споживчий ринок України: методологія дослідження та регулювання. Київ: КНЕУ. 2007. 379 с.

5. Лісіца В.В. Омніканальні продажі: тенденції, проблеми та перспективи розвитку в українському ритейлі. Проблеми і перспективи економіки та управління. 2017. № 2 (10). С. 100-110.

6. Попадинець Н.М. Основні тенденції та перспективи розвитку роздрібної торгівлі у сільській місцевості. Соціальноекономічні проблеми сучасного періоду України. Львів. 2016. Вип. 1(117). С. 16-19.

7. Popadynets N. Shults S., Barna M. Diferences in consumer buying behaviour in consumer markets of the EU member states and Ukraine. Economic Annals-XXI. 2017. № 166(1-2). pp. 26-30. https://doi.org/10.21003/ea.V166-05

8. Popadynets N., Kolomiyets I. Trade at Ukrainian internal market: the development mechanism. Actual problems of economics, 2016. №1(175). pp. 69-75.

9. Інноваційний розвиток підприємств сфрери торгівлі: світові тенденції та практика в Україні : монографія / [наук. ред. 
д.е.н., проф. С. А. Давимуки] ; ДУ «Інститут регіональних досліджень імені М. І. Долішнього НАН України». Львів, 2016.425 с.

10. Горбенко О.В. Ринок продуктової роздрібної торгівлі в Україні:формати, мережі, розвиток. Молодий вчений. 2015. № 669 (24). Ч. 1. С. 59-66.

11. ТОП 160 торговых операторов FMCG по количеству магазинов, первая половина 2019 г. Тенденции и обновленные прогнозы развития ритейлеров во второй половине 2019 г." URL: http://allretail.ua/research/139/

12. European B2C E-commerce Report 2016. URL: https://www.ecommerceeurope.eu/app/uploads/2016/07/European-B2CE-commerce-Report-2016-Light-Version-FINAL.pdf

13. В Україні на початок 2017 року нараховано 21,6 млн користувачів інтернету. URL: https://promo.semantrum.net/uk/2017/04/21/v-ukrayini-na-pochatok-2017-roku-narahovano-21-6-mln-koristuvachiv-internetu/

14. Гліненко Л. К ., Дайновський Ю.А. Стан і перспективи розвитку електронної торгівлі України. Маркетинг і менеджмент інновацій, 2018, № 1. С. 83-102.

\section{References:}

1.Azaryan, O. M., Loktyev, E. M., Sarkisyan, L. H., Khallir, B., Sobolyev, V. O., Harkusha, D. V. (2009). Suchasni tendentsiyi rozvytku rozdribnoyi torhovelnoyi merezhi. [Garkusha DV Modern tendencies of retail trade network development]. Donetsk: DonDUET.

2.Apopiy, V. V., (2012). Systema rehulyuvannya vnutrishnoyi torhivli Ukrayiny [System of Regulation of Internal Trade of Ukraine]. Kiev: Academic.

3. Vasyltsiv, T. H., Voloshyn, V. I., Boykevych, O. R., Karkavchuk, V.V. (2012). Finansovo-ekonomichna bezpeka pidpryyemstv Ukrayiny: stratehiya ta mekhanizmy zabezpechennya [Financial and Economic Security of Ukrainian Enterprises: Strategy and Mechanisms]. Lviv: League Press.

4.Lihonenko, L. O. (2007). Spozhyvchyy rynok Ukrayiny: metodolohiya doslidzhennya ta rehulyuvannya [Consumer market of Ukraine: methodology of research and regulation]. Kyiv: KNEU.

5.Lisitsa, V.V. (2017). Omnikanalni prodazhi: tendentsiyi, problemy ta perspektyvy rozvytku v ukrayinskomu ryteyli [Omnicanal sales: trends, problems and development prospects in Ukrainian retail]. Problemy i perspektyvy ekonomiky ta upravlinnya - Problems and prospects of economy and management, 2(10), 100-110.

6.Popadynets, N.M. (2016). Osnovni tendentsiyi ta perspektyvy rozvytku rozdribnoyi torhivli u silskiy mistsevosti [The main trends and prospects of development of retail trade in rural areas]. Sotsialno-ekonomichni problemy suchasnoho periodu Ukrayiny Socio-Economic Problems of the Modern Period of Ukraine, 1(117), 16-19.

7.Popadynets, N. Shults, S., Barna, M. (2017. Diferences in consumer buying behaviour in consumer markets of the EU member states and Ukraine. Economic Annals-XXI, 166(1-2), 26-30. https://doi.org/10.21003/ea.V166-05

8.Kolomiyets, I., Popadynets, N. (2016). Trade at Ukrainian internal market: the development mechanism. Actual problems of economics, 1(175), 69-75.

9.Davymuky, S. A. (Eds) (2016). Innovatsiynyy rozvytok pidpryyemstv sfery torhivli: svitovi tendentsiyi ta praktyka v Ukrayini [Innovative development of enterprises in the sphere of trade: world tendencies and practice in Ukraine]. Lviv: SI "Dolishniy Institute of Regional Research of NAS of Ukraine".

10. Horbenko, O.V. (2015). Rynok produktovoyi rozdribnoyi torhivli v Ukrayini:formaty, merezhi, rozvytok [The grocery retail market in Ukraine: formats, networks, development]. Molodyy vchenyy - Young scientist, 669(24), 59-66.

11. Allretail (2019). TOP 160 torgovykh operatorov FMCG po kolichestvu magazinov, pervaya polovina $2019 \mathrm{~g}$. Tendentsii $\mathrm{i}$ obnovlennyye prognozy razvitiya riteylerov vo vtoroy polovine $2019 \mathrm{~g}$. [TOP 160 FMCG retail operators by the number of stores, first half of 2019 Trends and updated forecasts for retailers in the second half of 2019]. URL: http://allretail.ua/research/139/

12. European B2C E-commerce Report 2016. (2016). URL: https://www.ecommerceeurope.eu/app/uploads/2016/07/European-B2C-E-commerce-Report-2016-Light-Version-FINAL.pdf

13. Promo (2018) V Ukrayini na pochatok 2017 roku narakhovano 21,6 mln korystuvachiv internetu [In the beginning of 2017 , there were 21.6 million Internet users in Ukraine]. URL: https://promo.semantrum.net/uk/2017/04/21/v-ukrayini-na-pochatok-2017roku-narahovano-21-6-mln-koristuvachiv-internetul

14. Hlinenko, L. K., Daynovskyy, YU.A. (2018). Stan i perspektyvy rozvytku elektronnoyi torhivli Ukrayiny [Tatus and Prospects of E-Commerce Development in Ukraine]. Marketynh i menedzhment innovatsiy - Marketing and Innovation Management, 1, 83-102.

Danylo Svitlana, PhD, Uzhhorod Trade and Economic Institute KNTEU (Uzhhorod, Ukraine)

Nature and development features of retail trade chains in Ukraine

Lately the retail chains have been gaining utmost importance, because they provide consumers with an opportunity to quickly, conveniently and with minimum losses of time and efforts purchase the necessary goods and services close to job or residence places in a certain time and in a certain number in conditions of free choice and wide range. Due to constant improvement of forms and methods of trade, unification of goods, competition, change of features and factors of impact on retail trade and its classification, it is 
worth adjusting classification features, characteristics and requirements with the modern patterns of stores for more profitable activity. Therefore, the development of retail chains gains increasingly new and important meaning. The paper outlines the features of forming and development of retail trade chains. Classifications of retail trade companies are examined. Characteristics and requirements to the patterns of retail chains are suggested. Recommendations regarding the improvement of retail chains activity are given. The paper proves that despite unstable political and economic situation and high shadow business component in the country, the retail trade chain remains one of a few sectors that is developing and not only increasing the profits, but also is an essential support for the whole economy of the country. We deem that each company has to use as big complex of measures as possible to strengthen its positions, keep available and attract new clients, increase their income and improve the economy of the country, namely: merchandizing system - range optimization, efficient planning of shop spaces, means of communicative and visual merchandizing; improvement of activity methods - for clients, agents, employees; improvement of activities related to financial and moral motivation for employees; considering of requirements to the patterns of retail chain stores.

Key words: competitiveness, retail trade, trade chains, consumers, stores patterns.

Дата надходження до редакції: 31.08.2019 р. 